\title{
Food Policy: Urban Farming as a Supplemental Food Source
}

\author{
Bessie DiDomenica \\ Walden University \\ Mark Gordon \\ Walden University
}

\begin{abstract}
Food policy has a unique role for public, nonprofit, private, and academic stakeholders. Growing food in the city is a challenge worldwide. Food systems can be destroyed by external (weather extremes) and internal (zoning regulations) forces. This study explores urban farms as a secondary food source and their common themes across four sectors. A Northeastern U.S. city was the case study to examine how it implemented its formal urban agriculture program. The positive social change implications of urban farms include greater food visibility and food access in low-income areas and more consumer awareness about growing fresh food. This study contributes a realistic view of urban farms: They are a secondary food source, but local food alone cannot feed large populations.
\end{abstract}

Keywords: food policy, urban farming, sustainable agriculture, public policy, urban agriculture, sustainability

\section{Introduction}

The U.S. Department of Agriculture defined urban farming or urban horticulture as the "science and art of promoting the successful growth and development of ornamental plants, turf, vegetables and fruit in the urban environment" ("Urban horticulture," n.d.). Urban farms revitalize abandoned land, foster community well-being, and improve the urban landscape. However, before urban farmers can sell food to the public, they must comply with strict regulations and food safety measures.

Our research was designed as a case study to explore the interactions between food policies and urban farms and their influence on urban communities. Interviews, field notes, journals, and document analysis provided the data for this study. The sample included 20 participants representing four sectors: public (urban agriculture [UA], urban planning, food system planning), nonprofit (managers who train new farmers), private (entrepreneurs, small commercial growers), and academic (administrators, students in food policy, sustainable agriculture). Sample documents for analysis included

- the U.S. Department of Homeland Security's (2013) National Infrastructure Protection Plan (to protect key resources to ensure national security; www.dhs.gov),

- the U.S. Department of Homeland Security's (2012) Operation Liberty Shield (to maintain the flow of goods with minimal disruption to the U.S. economy; www.fema.gov), and

- the Environmental Protection Agency's (2011) Urban Farm Business Plan Handbook (to help urban farmers write a business plan; www.epa.gov). 
Urban farms have several implications for positive social change. Our study provides a snapshot of a specific food system in a Northeast city. We found little competition within the urban farming landscape that is relatively small (less than 20 established urban farms versus over 5,000 conventional farms statewide). Less competition means that more people can grow food in many ways using portable planters, rooftops, windowsills, backyards, raised beds, or freight containers. Each type of farm is a resource that adds to the public food supply.

Another implication is that urban farms increase food visibility and may even promote healthy fresh food options in the standard America diet. The presence of urban farms improves consumer awareness about fresh foods and provides greater access in low-income areas as people see that they can grow food for themselves. Eating fresh food can reduce diet-related diseases and potentially improve the overall health of low-income populations.

Finally, although space is limited in the city, urban farms illustrate that food can grow on microplots of land (less than one quarter acre) and by using technology (aquaponics, hydroponics). New sources of land may be available through brownfield sites or land originally zoned for industrial or commercial use. Through remediation or removing toxins and chemicals from the land, it can be converted for agricultural use.

\section{A History of Urban Agriculture}

Since the Middle Ages, farmers have exploited UA to satisfy the food needs of cities. Wars and natural disasters were opportunities to find other ways to grow food. Any available space was space to grow fresh fruits and vegetables, medicine, herbs, and flowers. For instance, the people of Machu Picchu in Peru designed UA infrastructures around irrigation, food storage, terraces, and climate control (Taylor Lovell, 2010). In the 1890s, officials in Detroit, Michigan, launched the Potato Patch program to encourage people to start urban gardens and temporarily farm land on vacant lots. During the war years, the U.S. government encouraged schoolchildren and families to cultivate victory gardens to supplement their diets with fresh food. In England throughout the Industrial Revolution, the government gave workers allotment gardens to grow food, a practice that continues today.

\section{Horticulture or Agriculture?}

We made a clear distinction between horticulture and agriculture: Horticulture (organic agriculture) is a process that reflects patterns in nature, such as rotating crops, composting, and recycling rain water. The goal is to develop complementary processes in an ecosystem to withstand internal (population growth) and external (weather extremes) pressures. Hemenway (2011) suggested that horticulture offers simple ways to grow food and provides long-term solutions to feed people over multiple generations. It also favors sustainability as described in Brundtland's food policy theory (The World Commission on Environment and Development, 1987).

In contrast, agriculture is resource-intensive food production and is highly dependent on fossil fuels. Agriculture is today's large-scale industrial agriculture, a process that drives the global food supply chain. The depth and breadth of this food supply chain has created an imbalance between inputs (water and land) and outputs (amount of food produced). Godfray et al. (2010) noted that while industrial agriculture is the primary source of food in many cities, it is also short-term and unsustainable food production. 
The similarity between horticulture and agriculture is in growing food, but their practices are quite different. Unlike organic agriculture, industrial agriculture is not self-replenishing and Hemenway challenged the notion that agriculture is a sustainable process based on its resource-intensive practices. As mentioned, the current global food supply chain is vulnerable due to an imbalance in resources. One advantage of urban farms is that they offer alternative ways to grow food and encourage farming in limited spaces (rooftops, containers, window sills), all common features in modern cities. Finally, anyone can grow food for him- or herself, a process that contributes to the public food supply.

\section{The Farm Bill and Brundtland's Theory}

Food policy is a relatively new specialty of public policy. Historically, food policy developed from studies on industrial agriculture or the "Green Revolution" recognized by researchers as highvolume, selective food production (Clark, Munroe, \& Mansfield, 2010; Wiskerke, 2009). When farming equipment replaced workers and simple farming practices, the global food system changed forever. Agricultural technologies forged a gap between rich and poor countries: Industrialized farmers in Europe and the United States overwhelmed small farmers in the Caribbean, Asia, and Latin America. Poor farmers face ongoing struggles to compete in the global marketplace (Angelo, Timbers, Walker, Donabedia, \& Van Noble, 2011; Hemenway, 2011; Zerbe, 2010; The World Commission on Environment and Development, 1987).

Food policy is also part of the expansive United States Agricultural Adjustment Act of 1938 (farm bill) drafted in the 1930s. The farm bill was initially designed to subsidize poor farmers to control excess food production. According to the U.S. Senate Committee on Agriculture, Nutrition, and Forestry (n.d.), the 2014 farm bill is a "national agriculture, nutrition, conservation, and forestry policy" (para 1) and favors large industrial agriculture businesses with subsidies and other incentives. The farm bill subsidizes farming practices such as chemical agriculture, synthetic fertilizers, and hormone-fed livestock, which are contrary to urban farming practices.

However; UA and urban farming may not directly benefit from farm bill subsidies. The scarce funds for small family farms and urban farms mainly support marketing rather than infrastructure and start-up capital. Sample programs include the Farmer-to-Consumer Direct Marketing Act of 1976 used to expand the marketing of local foods (Hardesty, 2010). According to the California Certified Organic Farmers, farm bill complexities make it hard for small-scale farmers to survive. There are associated fees for organic farmers: an initial application fee $(\$ 1,200)$ and yearly inspection and recertification fees (around \$900).

Brundtland's food policy theory is less familiar than the farm bill. This theory evolved from the United Nations' document Our Common Future that addressed problems of food security in poor countries. During the 1980s, food security (conditions that determine the flow of food through a community) was a growing problem in poor nations that struggled with ongoing poverty, starvation, and limited support from the global community. Brundtland's theory favored new food policies to counteract a food crisis by growing food using commercial agriculture (The World Commission on Environment and Development, 1987). While commercial agriculture was fast-growing, large-scale agriculture, it also relied on the heavy use of natural resources (water, land) and favored chemicals, pesticides, and hormone-fed livestock.

First, Brundtland acknowledged that short-term solutions would not end starvation. The theory introduced the term sustainability as a process to grow food for present and future generations. 
Brundtland connected nature to human survival, provided a global action plan, and recognized that food was an important concern for the global community.

Second, Brundtland's theory was a segue to contemporary food production. The idea was to understand the holistic quality of food and the relationships between conserving natural resources for human survival to feed multiple generations. The Food and Agriculture Organization of the United Nations (2011) recommends food policies that increase agricultural productivity, favor resilient food and agriculture systems, and support small-scale rural and urban farmers. Urban agriculture is a process to grow food in the city. This is a critical factor based on the United Nations' prediction of a global population of nine billion by the year 2050. Brundtland's theory applies to practical ways to grow food within the limits of nature.

Finally, the farm bill controls the public food supply and supports limited and selective crop production by high-volume growers. The third reason for Brundtland's theory was to expand the public food supply through alternative and sustainable food production, such as UA and urban farming.

\section{Research Findings Across Sectors}

Our research revealed three common themes across the public, nonprofit, private, and academic sectors.

\section{Theme 1: Land and Food Policy}

Public sector officials in food policy, urban planning, and environmental protection, implement and design food and land policies at the city, local, and state level. For example, the city in our study drafted the City Ordinance (Ordinance), which changed zoning regulations and identified standards for UA practices within city limits. Officials described different UA practices, design, maintenance, and public safety regulations for growing food. The Ordinance outlined UA processes that use public or private land to grow food on the ground or through other agricultural technologies (aquaponics, hydroponics, aquaculture).

An interesting element of this sector is that it controls food system activities and is a primary (public) and secondary (buy land from private landowners) source of land. Also, officials can offer selective financial incentives and subsidies that help or harm food production through food safety regulations and land use restrictions. Although public land is scarce, officials can buy private land and determine the use of public lands.

Innovation in food production might include areas overlooked such as brownfield sites (land previously used for commercial or industrial use). Public officials converted public land into "healthfields" for urban farming after the land is assessed and cleaned up for agricultural use. While remediation of these sites is costly, they offer a real alternative to finding land for urban food production. In this sector, food production can involve food safety regulations and financial incentives. As mentioned, stakeholders support a food system plan as a vision for overall food production. It could serve as a baseline for regional food production.

The nonprofit sector has partnerships with city, local, and state agencies and has leadership roles in the several communities. Sector participants were the main recipients of valuable food and land policies. For instance, city officials offered public land at a significant discount for nonprofits to buy or lease. Nonprofits are also favored by an important land trust organization that bought public 
land, cleaned it up, sold, and transferred the land rights to nonprofits for urban farming and related UA projects.

Further, nonprofits have a strong historical, cultural, and community presence as well as deep connections with businesses, foundations, community groups, and public agencies. Nonprofit stakeholders gain the advantage over other sectors based on opportunities to buy land, their access to funding, and an extensive network of resources.

Private sector stakeholders serve on the state Food Policy Council and remain active in food policy decisions. Other stakeholders were involved in the preliminary discussions when the Ordinance was evolving in early 2010. These stakeholders gained a clear understanding of food policies and integrated that knowledge into their business planning for a commercial farm.

In one case, the rooftop farmer used a simple farming practice and applied for a temporary annual permit with fewer structural and public safety regulations. The farmer explained,

We farm in portable container planters. So because they [containers] are removable from the roof and not something that was changing the structure ... we were able to apply to the City for the short form permit, which is very different process. It's much quicker.

Another stakeholder launched a commercial mobile food market based on the model of a social enterprise (a tax structure of a nonprofit combined with generating revenue for financial sustainability). However, this stakeholder was at odds with city food policies and was limited to selling food in certain areas.

Academic stakeholders have an ancillary role in food policy. For instance, stakeholders were involved in contributing comments to new federal food safety legislation; designed curriculum or studied food policy, environmental science, or food culture; and organized student-run food projects. Students worked on food policy issues in their communities (food and transportation, a follow-up study on a local UA ordinance) or applied for internships or fellowships in a nonprofit with programs in UA and urban farming.

In addition, academic stakeholders had resources to explore technology-based agriculture on campus or work on projects through their business and community networks. We found a stakeholder in a Midwestern city who discussed plans to help schools pass food safety regulations to grow, harvest, and consume food on public school property.

\section{Theme 2: Food Production}

Public officials recognize that food production includes urban farms and gardens. Both are critical because many urban farmers start out as urban gardeners. These stakeholders acknowledged that farming was a business and should include a business plan, hands-on farming experience, and collaboration with different partners.

Further, state officials are developing a food system plan for regions statewide. The plan will serve as a baseline of agricultural processes and provide a mechanism to help local officials protect agriculture. The revised plan should include input from urban farmers and UA groups, local and state officials, nonprofits, food policy, and water resources stakeholders.

Nonprofit stakeholders receive funding to train new farmers and develop other UA projects. Nonprofits grow food for themselves, to donate, sell, and have community agriculture programs to 
expand food production in urban, rural, and suburban communities. Nonprofits favor collaboration between different types of farmers, such as growing food outside the city to deliver to farmers' markets, community-supported agriculture (CSA) groups, or food stands.

Nonprofits offer primarily social service programs and food production is secondary. This strategy means that nonprofit managers grow food for themselves and to improve food access in the communities in which they serve. They also sell food at affordable prices in low-income areas, or at premium prices to restaurants, and benefit from public subsidies and access to land.

The private sector is the main source for new urban farmers. We found a variety of farmers including conventional or traditional farmers, aboveground farmers (technology-based), and a mobile food market. Each group of farmers sold food to a diverse market such as low-income and high-income consumers and CSA groups.

One farmer was near retirement and hoped to keep the farm in the family: "This farm has been in your family for multiple generations correct. We need to grow, and we need some blood that is more iron rich. It's time for me to move on." Another farmer used an innovative social enterprise business called a mobile food market - unlike a traditional food truck, a mobile food market can source food from local and nonlocal growers. Other farmers had a rooftop farm and sold specialty crops (salad greens) at premium prices but struggled with low-volume production. These farmers also worked other part-time jobs because the farm was not generating enough profit.

Farming and financial viability are in conflict because of the overall low wages associated with the agricultural workforce. While there is a growing interest, one farmer suggested that urban farms might expand through hobby farming where people grow food with no expectations of making a profit: "And right now it's certainly a job and but it's still kind of more of a hobby in ways because we aren't getting paid for it, you know?"

The academic sector may be the likely leaders in food production because they have the resources to experiment with different growing practices. The trial and error element of food production is critical due to unforeseen factors (weather, pests, disease, equipment failure) which can quickly destroy a crop. Further, these stakeholders favored technology-based agriculture-greenhouses, aquaponics, hydroponics, aboveground farming, raised-bed farms and other innovations. In addition, universities also benefit from outdoor campus spaces available for agriculture, beekeeping, or growing specialty crops.

\section{Theme 3: Procurement}

Public officials buy food from local growers. For instance, there is a federal mandate for public schools to establish a wellness policy and provide healthy and nutritious foods, promote exercise, and food education for students. One official in a school system tries to buy food from local growers: "We source through our primary produce distributor and they're sourcing from farms within a 100-mile radius of [the city]."

But the challenge for small local growers is to reach high-volume production and consistency to feed over 15,000 schoolchildren daily. The school system buys organic, fresh and local food when possible and frozen and conventional foods as needed. In reality, local food is expensive and has a low-volume capacity. The official suggested that local food cannot provide all the food needs of urban areas.

In addition, federal farming subsidies benefit large commercial growers who transport food over long distances. Another official explained that "Local food producers, small producers, are not subsidized 
by the government, only the large extensive capital producers are subsidized by the government. So that's the playing field that we have to develop local agricultural systems."

Nonprofit stakeholders acknowledged the public demand for local food. But the ability to procure fresh, organic foods was concentrated in wealthy neighborhoods. Nonprofit managers recognized that people pay more for quality food and priced the foods at farmers' markets differently based on location (wealthy or poor communities). For instance, more food variety was offered to wealthy consumers who can pay more, compared to low-income consumers who struggle with less money. As such, the link between procurement, distribution, and access was in relation to the economics of a community. There is an economic factor involved and nonprofits sell fresher, higher quality produce to consumers who can pay higher prices.

Procurement in the private sector may depend on the communities in which the farmers serve. Creativity and a good business model were critical. For example, the mobile food market owner bought food from one source and had multiple distribution streams in low-income Jamaican, Irish, or Asian communities. The mobile food market provided fruits and vegetables to serve the unique food culture of each community and did not source all food locally.

One farmer explained,

The majority of our food comes from a third party vendor. We worked with [a commercial farm] ... the challenge we encounter too is that the wholesale price of local food at the volume that we're buying is prohibitively expensive for our [low-income] families.

For the rooftop farmers, sourcing food from local and nonlocal suppliers was a practical business model. They sold specialty crops to higher end restaurants, retail stores, and at a farm stand in an office building. The commercial farmer also had a limited distribution stream, sold only within $10 \mathrm{mi}$ of the farm, made a few deliveries to "white tablecloth, high end restaurants," supplied food for a large CSA group, and had a Saturday farmers' market.

Academic stakeholders recognized that procurement was a big part of the demand for local foods. This sector may be most able to meet consumer demand because of campus resources (campus areas to grow food, funding opportunities). There are business opportunities for universities and colleges to promote UA or local food in general. The Appropriate Technology Transfer for Rural Areas organization suggested that local procurement could improve through season extension practices (hoop houses, greenhouse, wind machines) to protect crops from frost or heat year round.

This sector is most likely to use sustainable agriculture and experiment with different ways to procure food. The sector has funding for student-run agriculture projects and can apply technology to procure a variety of crops. For example, one student worked on a sustainable food procurement plan and procurement was also a concern for large food suppliers:

There is a new cafe on campus run by [a large food service supplier] ... Food producers come in to explain their product to students, and the seating is made of recycled Coke bottles or reclaimed [local] wood. Seeing the procurement change is certainly encouraging.

See Table 1 for a theme comparison and Table 2 for the findings by sector. 
Table 1: Comparing Themes Across Four Sectors

\begin{tabular}{|c|c|c|c|}
\hline Sector & $\begin{array}{l}\text { Local Food and } \\
\text { Land Policy }\end{array}$ & $\begin{array}{c}\text { Food Production } \\
\text { (Grow Food) }\end{array}$ & $\begin{array}{c}\text { Procurement } \\
(\text { Get Food })\end{array}$ \\
\hline Public & $\begin{array}{l}\text { Both policies could } \\
\text { help or harm } \\
\text { urban farms }\end{array}$ & $\begin{array}{l}\text { Source of vacant public } \\
\text { land (primary) and } \\
\text { brownfields, } \\
\text { underutilized, } \\
\text { abandoned land } \\
\text { (secondary) for food } \\
\text { production }\end{array}$ & $\begin{array}{l}\text { Supports cross-sector } \\
\text { alliances with local } \\
\text { growers, institutions, } \\
\text { and funding for } \\
\text { nonprofits and large } \\
\text { food producers }\end{array}$ \\
\hline Nonprofit & $\begin{array}{l}\text { Both policies had a } \\
\text { positive impact } \\
\text { in this sector }\end{array}$ & $\begin{array}{l}\text { Mission includes social } \\
\text { programs and food } \\
\text { production (urban } \\
\text { farms, backyard } \\
\text { gardens, partnerships } \\
\text { with other farmers) }\end{array}$ & $\begin{array}{l}\text { Procure food from large } \\
\text { growers for CSA } \\
\text { memberships, also sell } \\
\text { in lower income and } \\
\text { higher income } \\
\text { communities }\end{array}$ \\
\hline Private & $\begin{array}{l}\text { Both policies had a } \\
\text { negative impact } \\
\text { in this sector }\end{array}$ & $\begin{array}{l}\text { Commercial food } \\
\text { production using } \\
\text { technology, } \\
\text { conventional farming, } \\
\text { or creative business } \\
\text { models }\end{array}$ & $\begin{array}{l}\text { Procure food from local or } \\
\text { nonlocal producers, } \\
\text { distribution stream in } \\
\text { premium markets } \\
\text { (higher end } \\
\text { restaurants, farmers' } \\
\text { markets) or lower } \\
\text { income communities }\end{array}$ \\
\hline Academic & $\begin{array}{l}\text { Both policies can } \\
\text { evolve internally } \\
\text { (on campus) or } \\
\text { external (in the } \\
\text { community) }\end{array}$ & $\begin{array}{l}\text { Experiment with trial- } \\
\text { and-error crop } \\
\text { production and } \\
\text { technology-based } \\
\text { agriculture }\end{array}$ & $\begin{array}{l}\text { Procurement fuels } \\
\text { consumer demand for } \\
\text { local foods, and } \\
\text { improves season } \\
\text { extension practices for } \\
\text { more crop variety }\end{array}$ \\
\hline
\end{tabular}

Note. $\mathrm{CSA}=$ community-supported agriculture. 
Table 2: Findings by Sector

\begin{tabular}{|c|c|c|c|c|}
\hline Sector & $\begin{array}{c}\text { Food and Land } \\
\text { Policy }\end{array}$ & Food Production & Procurement & Outliers \\
\hline Public & $\begin{array}{l}\text { Key stakeholders } \\
\text { in policy design } \\
\text { and } \\
\text { implementation }\end{array}$ & $\begin{array}{l}\text { Guide urban } \\
\text { agriculture and } \\
\text { urban farming } \\
\text { projects } \\
\text { through } \\
\text { funding } \\
\text { opportunities }\end{array}$ & $\begin{array}{l}\text { Support local } \\
\text { and } \\
\text { nonlocal } \\
\text { food } \\
\text { producers }\end{array}$ & $\begin{array}{l}\text { Extensive programs } \\
\text { to promote } \\
\text { agriculture } \\
\text { practices in state } \\
\text { (City Ordinance, } \\
\text { food policy } \\
\text { council) but only } \\
\text { one person in } \\
\text { urban agriculture } \\
\text { division }\end{array}$ \\
\hline Nonprofit & $\begin{array}{l}\text { Influence land and } \\
\text { food policy } \\
\text { through the } \\
\text { land trust } \\
\text { nonprofit }\end{array}$ & $\begin{array}{l}\text { Urban farming } \\
\text { secondary to } \\
\text { mission and } \\
\text { social service } \\
\text { programs }\end{array}$ & $\begin{array}{l}\text { Grow food to } \\
\text { feed self, } \\
\text { people in } \\
\text { social } \\
\text { service } \\
\text { programs, } \\
\text { donate to } \\
\text { community } \\
\text { groups }\end{array}$ & $\begin{array}{l}\text { Deep network } \\
\text { across multiple } \\
\text { sectors, strong } \\
\text { support from } \\
\text { local and state } \\
\text { government }\end{array}$ \\
\hline Private & $\begin{array}{l}\text { Active on state } \\
\text { food policy } \\
\text { council, and } \\
\text { involved in } \\
\text { planning stages } \\
\text { of the City } \\
\text { Ordinance } \\
\text { policy for urban } \\
\text { agriculture }\end{array}$ & $\begin{array}{l}\text { Grow food on the } \\
\text { ground, } \\
\text { aboveground, } \\
\text { only sector for } \\
\text { small } \\
\text { commercial } \\
\text { growers }\end{array}$ & $\begin{array}{l}\text { Mainly source } \\
\text { locally, but } \\
\text { also get food } \\
\text { from } \\
\text { nonlocal } \\
\text { sources to } \\
\text { bring ethnic } \\
\text { crops to low- } \\
\text { income } \\
\text { areas }\end{array}$ & $\begin{array}{l}\text { Best opportunities } \\
\text { to engage new } \\
\text { business and new } \\
\text { farmers, but little } \\
\text { access to public } \\
\text { investment }\end{array}$ \\
\hline Academic & $\begin{array}{l}\text { Developed an } \\
\text { institute on } \\
\text { sustainable } \\
\text { agriculture, } \\
\text { land } \\
\text { conservation, } \\
\text { and } \\
\text { environmental } \\
\text { policy }\end{array}$ & $\begin{array}{l}\text { Unlikely leaders } \\
\text { with capacity to } \\
\text { grow food on } \\
\text { campus farms } \\
\text { and rooftops, } \\
\text { and in } \\
\text { greenhouses }\end{array}$ & $\begin{array}{l}\text { Provides food } \\
\text { for large } \\
\text { vendors } \\
\text { interested } \\
\text { in buying } \\
\text { local food, } \\
\text { large } \\
\text { network of } \\
\text { partners }\end{array}$ & $\begin{array}{l}\text { Institutional } \\
\text { support to } \\
\text { encourage } \\
\text { student-run food } \\
\text { projects and } \\
\text { promoting } \\
\text { entrepreneurship } \\
\text { versus training } \\
\text { for new farmers }\end{array}$ \\
\hline
\end{tabular}




\section{Food Policy Complexities}

Our study revealed that the challenges of food policy include its many complexities and contradictions. Growing food in the city can be a simple idea that is hard to implement. There are inconsistencies in food policies that contribute to these challenges. For instance, one food policy complexity is the farm bill itself, originally designed to subsidize poor farmers who could not sell their surplus crops. But today, the farm bill provides subsidies to high-volume industrial growers and has few support systems for small-scale farmers. This creates a problem because the global food supply relies on industrial agriculture processes that favor long transport miles, exposure to foodborne diseases, chemical agriculture, and hormone-fed livestock (Maxwell \& Slater, 2003; Zerbe, 2010). The result has created a weak food system that is not sustainable.

Other complexities are land policies that support one food producer over another. We found that city and state land policies benefit nonprofits by selling them public land at a significant discount. In addition, community land trusts can partner with government agencies and remediate the land sold to nonprofits. Private commercial farmers have no access to these benefits because such policies were developed for organizations (nonprofits) rather than the individuals (urban farmers, small-scale food producers). Such contradictions, in turn, limit the expansion of urban farms, even with a need for more local growers and increased consumer demand for local foods.

Finally, an interesting food policy complexity is that small-scale urban farmers will more likely have to use technology-based agriculture to grow food. With little available land in the city, farmers will look to hydroponics, aquaponics, and rooftop farms to grow food. The associated start-up capital and specific building codes (height restrictions, fire safety, weight, lighting restrictions on rooftop farms) will increase costs for small-scale growers, compared to simple on the ground (raised-bed) farming. These complexities further limit the profits of small-scale commercial farmers as well as contract the public food supply.

\section{A Summary of Urban Farm Projects in Different Cities}

\section{Viet Village Urban Farm: New Orleans, Louisiana}

Truitt's 2012 study described a rebuilding process for neighborhoods destroyed by Hurricane Katrina. Officials selected communities to create economic growth through "a smaller and more efficient post-Katrina New Orleans." One project was the Village de l'Est, a Vietnamese neighborhood in New Orleans that already had a well-established urban garden. City officials wanted to rename the garden the Viet Village Urban Farm (VVUF) and change it into a green technology and sustainable agriculture enterprise. Most of the gardeners were elderly, but the VVUF was a plan for future generations and commercial growers.

Although the project had adequate funding, officials failed to include amenities for the Vietnamese culture. People supported the community garden because it defined the neighborhood's unique culture. Members of the community believed an urban farm was a modern representation of green technologies (recycling, energy efficiency). People did not favor commercial growth at the expense of losing their community garden. In the end, VVUF failed in several ways: City officials implied that the community garden was not sustainable and that the gardeners used contaminated water from a nearby landfill. 


\section{Right to Farm Laws: Detroit, Michigan; Youngstown, Ohio; Cleveland, Ohio; and Buffalo, New York}

Some interesting land policy regulations also apply to urban farms. Heckler (2012) described the impact of the right to farm laws on urban farming in Detroit, Youngstown, Cleveland, and Buffalo. These cities have an abundance of empty properties for agricultural use, although local and state regulations limit the growth of urban farms. For example, there are logistical challenges in Detroit, such as limits on farming operations in a residential area or restricted use of pesticides near a work zone or school. But the right-to-farm laws protect urban farmers from nuisance lawsuits even when they use harmful farming practices. Comprehensive legislation might provide a broad, statewide solution to urban farming and help local governments design useful zoning regulations to expand urban farms.

\section{Produce From the Park: Baltimore, Maryland}

A study by Hu, Acosta, McDaniel, and Gittelsohn (2011) discussed Produce From the Park. This nonprofit bought 6 acres of land in Baltimore to "improve community access to produce, promote localized food consumption, provide experience-based learning opportunities for students, and establish urban farming as a source of community development" (p. 70).

An interesting summary of interviews with African Americans (between 30 and 50 years of age) described their views on healthy foods:

- Food choices involved food culture and preferences, rather than cost and access. The old school or Southern food that was "overcooked and fried" gave people a sense of nostalgia.

- People were hesitant to eat "mainstream White" food. There was a negative association with healthy foods but not with sugary, processed foods.

- People did not know the difference between healthy and unhealthy food and relied on TV commercials that promoted unhealthy foods.

- Some people did not see a link between obesity, diabetes, and poor eating habits.

- Urban farming was perceived as "getting their hands dirty," an association with White landowners and slavery.

Such comments reflect the overall confusion about food. If Produce From the Park hoped to engage people in the community, they might include farm stands of fresh fruits and vegetables located in high traffic areas and provide basic classes on good health and eating fresh food.

\section{Conclusion}

Our study was designed to understand the role of urban farms as a secondary food source. We learned that urban farming plays a different role in different sectors. In the public sector, urban farms were a unique food source separate from industrial agriculture. Local officials implemented a special UA ordinance to increase ways for people to grow food, using raised beds, backyard, and rooftop farming. Urban farming was a critical part of the Ordinance. 
The private sector designed urban farms to generate profits. While these farmers had the fewest resources (little access to land, high start-up costs and overhead) they also provide more opportunities to create jobs in the agriculture industry. It is challenging for small-scale urban farmers to generate a profit because of evolving food safety regulations and additional fees for organic growing practices. Some urban farmers use technology-based agriculture to grow food aboveground and on rooftops.

Overall, the results of our research were mixed. The limitation of urban farming was that it remains decentralized. Several nonprofit and institutions benefit from partnerships, but the small commercial farmer was excluded. While the situation creates a monopoly for nonprofits, but the industry is wide open to innovation and creativity in food production. However, without an infrastructure to finance or capture new ideas, opportunities for growth are limited. We predict that small-scale commercial farmers will have to rely on low-volume production and creative distribution streams to make a profit.

We conclude that there is great potential for urban farms to become a secondary food source based on its variety in food production. We recognize that local food production alone cannot feed a large population. Urban farms are notoriously low production farms, and some only grow specialty cropsany demand for nonlocal food is outsourced.

At best, urban farms can be a valuable supplemental food source, if given adequate support and creative infrastructures. Part of that infrastructure includes community and political support. We observed that nonprofits already have effective support networks. In contrast, the private sector had mostly new farmers and small-scale commercial growers. A key part of their business model should include community outreach to develop a community presence and participation in local and state food policy councils.

\section{References}

Agricultural Adjustment Act of 1938, Pub. L. 75-430, 52 Stat. 31, §516. Retrieved from http://www.ag.senate.gov/download/agricultural-adjustment-act

Angelo, M. J., Timbers, A., Walker, M. J., Donabedia, J. B., \& Van Noble, D. (2011). Small, slow, and local: Essays on building a more sustainable and local food system. Vermont Journal of Environmental Law, 12, 353-378.

Clark, J. K., Munroe, D. K., \& Mansfield, B. (2010). What counts as farming: How classification limits regionalization of the food system. Cambridge Journal of Regions, Economy and Society, 3, 245-259. doi:10.1093/cjres/rsq018

Environmental Protection Agency. (2011). Partnership for sustainable communities: Urban farm business plan handbook. Retrieved from http://www.epa.gov/sites/production/files/201510/documents/1.urban_farm_business_plan_handbook_091511_508.pdf

Food and Agriculture Organization of the United Nations. (2011). The state of food insecurity in the world: How does international price volatility affect domestic economies and food security? Rome, Italy: Author. Retrieved from http://www.fao.org/docrep/014/i2330e/i2330e.pdf30e

Godfray, H. C. J., Beddington, J. R., Crute, I. R., Haddad, L., Lawrence, D., Muir, J. F., ... Toulmin, C. (2010). Food security: The challenge of feeding 9 billion people. Science, 327, 812-818. doi:10.1126/science.1185383

Hardesty S. D. (2010). Do government policies grow local food? Choices, 25. Retrieved from http://www.choicesmagazine.org/magazine/article.php?article=113 
Heckler, S. A. (2012). A right to farm in the city: Providing a legal framework for legitimizing urban farming in American cities. Valparaiso University Law Review, 47, 217-266.

Hemenway, T. (2011). Is sustainable agriculture an oxymoron? In M. Gerwin (Ed.), Food and democracy: Introduction to food sovereignty (pp. 120-126). Kraków, Poland: Alliance of Associations Polish Green Network. Retrieved from http://permaculturenews.org/files/Foodand-Democracy.pdf

Hu, A., Acosta, A., McDaniel, A., \& Gittelsohn, J. (2011). Community perspectives on barriers and strategies for promoting locally grown produce from an urban agriculture farm. Health Promotion Practice, 14, 1-7. doi:10.1177/1524839911405849

Maxwell, S., \& Slater, R. (2003). Food policy old and new. Development Policy Review, 21, 531-533. doi:10.1111/j.1467-8659.2003.00222.x

Taylor Lovell, S. (2010). Multifunctional urban agriculture for sustainable land use planning in the United States. Sustainability, 2, 2499-2522. doi:10.3390/su2082499

The World Commission on Environment and Development. (1987). Our common future. Oxford, United Kingdom: Oxford University Press.

Truitt, A. (2012). The Viet Village Urban Farm and the politics of neighborhood viability in postKatrina New Orleans. City \& Society, 24, 321-339. doi:10.1111/ciso.12003

U.S. Department of Homeland Security. (2013). NIPP 2013: Partnering for critical infrastructure security and resilience. Retrieved from http://www.dhs.gov/sites/default/files/publications/NIPP\%202013_Partnering\%20for\%20Criti cal\%20Infrastructure\%20Security\%20and\%20Resilience_508_0.pdf

U.S. Department of Homeland Security, FEMA. (2003).Operation Liberty Shield. Retrieved from http://www.fema.gov/news-release/2003/03/17/operation-liberty-shield

U.S. Senate Committee on Agriculture, Nutrition, and Forestry. (n.d.). 2014 Farm bill. Retrieved from http://www.ag.senate.gov/issues/farm-bill

Urban horticulture. (n.d.). United States Department of Agriculture, National Agriculture Library. Retrieved from http://agclass.nal.usda.gov/mtwdk.exe?s=1\&n=1\&y=0\&l=60\&k=glossary\&t=2\&w=urban+hor ticulture

Wiskerke, J. S. C. (2009). On places lost and places regained: Reflections on the alternative food geography and sustainable regional development. International Planning Studies, 14, 369 387. doi:10.1080/13563471003642803

Zerbe, N. (2010). Moving from bread and water to milk and honey: Framing the emergent alternative food systems. Humboldt Journal of Social Relations, 33, 4-30.

The Journal of Social Change, sponsored by Walden University, welcomes manuscripts focusing on interdisciplinary research in social change that improves the human condition and moves people, groups, organizations, cultures, and society toward a more positive future.

Walden University Publishing: http://www.publishing.waldenu.edu 